\title{
EFFECT OF CRUDE PALM OIL (CPO) PROTECTED BY FORMALDEHYDE ON PHYSICAL AND CHEMICAL QUALITY OF LAMB
}

\author{
N.C. Tiven ${ }^{1}$, L. M. Yusiati ${ }^{2}$ Rusman $^{2}$ and U. Santoso ${ }^{3}$ \\ ${ }^{1}$ Faculty of Agriculture, Pattimura University, \\ Jln. Ir. M. Putuhena Kampus Poka, Ambon. 97233 - Indonesia \\ ${ }^{2}$ Faculty of Animal Science and Industries, \\ Gadjah Mada University, Jln. Fauna 3 Yogyakarta 55281 - Indonesia \\ ${ }^{3}$ Faculty of Agricultural Technology, Gadjah Mada University, \\ Jln. Sosio Yustisia, Yogyakarta 55281 - Indonesia
}

Received January 04, 2015; Accepted February 20, 2015

\begin{abstract}
ABSTRAK
Penelitian ini dilakukan untuk mengetahui pengaruh crude palm oil (CPO) yang diproteksi dengan formaldehid terhadap kualitas kimia dan fisik daging domba. Rancangan penelitian yang digunakan adalah rancangan acak lengkap dengan 3 perlakuan dan 5 kali ulangan. Sebanyak 15 ekor domba lokal jantan berumur 9-12 bulan dengan bobot badan 14-17 kg dibagi menjadi 3 kelompok untuk perlakuan perlakuan ransum. Kelompok pertama hanya mendapat ransum basal (R0), kelompok kedua mendapat ransum basal dan 3\% CPO (R1), sedangkan kelompok ketiga mendapat ransum basal dan 3\% CPO yang diproteksi dengan 2\% formaldehid (R2). Data dianalisis statistik menggunakan analisis sidik ragam. Perbedaan antar perlakuan diuji lanjut dengan Duncan's New Multiple Range Test. Hasil penelitian menunjukkan bahwa penambahan CPO yang diproteksi dengan formaldehid (R2) dalam ransum meningkatkan kadar protein dan lemak daging $(\mathrm{P}<0,05)$, secara fisik daging lebih empuk $(\mathrm{P}<0,01)$ dengan susut masak yang lebih rendah $(\mathrm{P}<0,01)$. Ransum dengan $\mathrm{CPO}$ yang diproteksi dengan formaldehid, meningkatkan kualitas kimia dan fisik daging domba.
\end{abstract}

Kata kunci : CPO, formaldehid, kualitas kimia, kualitas fisik, daging domba

\begin{abstract}
This study was conducted to determine the effect of crude palm oil (CPO) protected by formaldehyde on chemical and physical quality of lamb. The research design applied was completely randomized design with 3 treatments and 5 replications Fifteen local male sheeps aged 9-12 months weighing 14-17 kg were divided into 3 groups for different ration treatments. The first group received only basal ration (R0), the $2^{\text {nd }}$ group received basal ration and $3 \%$ of CPO (R1), while the $3^{\text {rd }}$ group received basal ration and $3 \%$ of $\mathrm{CPO}$ protected by $2 \%$ of formaldehyde (R2). The data were analyzed by analysis of variance. The differences among treatments were tested by Duncan's New Multiple Range Test. The results showed that the addition of CPO protected by formaldehyde (R2) in the sheep diet increased lamb protein and fat content $(\mathrm{P}<0.05)$, produced tenderer lamb $(\mathrm{P}<0.01)$ with lower cooking loss $(\mathrm{P}<0.01)$. The diet with $\mathrm{CPO}$ protected by formaldehyde can improve the chemical and physical quality of meat sheeps.
\end{abstract}

Keywords: CPO protected by formaldehyde, chemical quality, physical quality, lamb

\section{INTRODUCTION}

Fatty acids in ruminant meat were dominated by saturated fatty acids. This is becaused unsaturated fatty acids (linoleic-C18:2 and linolenic-C18:3) in the diet are hydrogenated by 
rumen microbes become saturated fatty acids, especially stearic acid (C18:0) (Jenkins et al., 2008; Wang et al., 2010), so that only about $10 \%$ joined the lipid tissues (Wood et al., 2008), whereas $90 \%$ were hydrogenated into saturated fatty acids. Based on the final product, hydrogenation of unsaturated fatty acids are completely done by two groups of bacteria, namely (1) group $\mathrm{A}$, which hydrogenate C18:2 and $\mathrm{C} 18: 3$ with the final product of trans-C18: 1; and (2) group B, which hydrogenate trans-C18:1 with the final product of C18:0 (Bauman et al., 2003).

In addition, unsaturated fatty acids in ruminants diet would disturb rumen fermentation and reduce the utilization of fiber (Hristov et al., 2009; Vafa et al., 2009). This is caused fat can wrap feed particles and close access of microbial cell membrane to contact feed, thereby disrupting the enzymes production to degrade feed, so that decrease feed digestibility and meat quality.

The in vitro study has been done using crude palm oil (CPO) as a source of unsaturated fatty acids as much as $0 \% ; 1.5 \% ; 3 \% ; 4.5 \% ; 5 \%$ and $6 \%$ of the dry matter that is mixed by expired milk powder (1:2) and protected with technical formaldehyde as $0 \% ; 1 \% ; 2 \%$ and $3 \%$ of the mixture. The result showed that $\mathrm{CPO}$ as much as $3 \%$ of the dry matter protected with $2 \%$ of formaldehyde can protect unsaturated fatty acids from rumen microbial hydrogenation and no negative effect on fermentation parameters and rumen microbial activity (Tiven et al., 2011). This is in line with Kitessa et al. (2001) and de Veth et al. (2005) research, that protection of fat with formaldehyde can reduce the hydrogenation of unsaturated fatty acids in feed by rumen microbial.

Results of in vitro studies need to be applied in vivo to determine the effect of $\mathrm{CPO}$ protected with formaldehyde in the diet on the chemical and physical quality of lamb. The success of this study is expected to be a reference using this feed that is high in saturated fatty acids to improve chemical and physical quality of lamb in order to reduce consumers susceptibility to cardiovascular disease.

\section{MATERIALS AND METHODS}

\section{Animals and Feed}

Fifteen of local male sheep aged 9-12 months with a body weight of about 14-17 kg were raised in individual equipped with places to eat and drink. Sheeps were randomly divided into 3 groups according to the treatment of feed; each group consisted of 5 animals. Completely randomized design was used in this study.

Basal diet was consisted of forage and concentrate with a ratio of 60:40. Forage used was elephant grass, while the concentrates were consisted of $30 \%$ rice bran and $10 \%$ soybean meal. Nutrient contents of basal ration were $62.98 \%$ of total digestible nutrients, $45.5 \%$ of dry matter, $14.48 \%$ of crude protein, $4.70 \%$ of crude fat and $21.93 \%$ of crude fiber. The first group received only the basal diet (R0), the $2^{\text {nd }}$ group received the basal diet and $3 \%$ of CPO (R1), while the $3^{\text {rd }}$ group received the basal diet and $3 \%$ of CPO protected with $2 \%$ formaldehyde (R2).

\section{Chemical and Physical Meat Properties}

After feed treatment for 3 months, sheep were slaughtered. Halal slaughtering is done, starting with the neck cut to the jugular vein severed, esophagus, and trachea (near the lower jaw bone). The Longissimus dorsi (LD) muscle on the back of the carcass were taken for analysis of chemical meat composition (AOAC, 2005) and meat physical properties, consisting of $\mathrm{pH}$ (AOAC, 2005), water holding capacity using Hamm's method (Soeparno, 2005), tenderness with Warner Bratzler tools and cooking loss (Suryati et al., 2008).

\section{Data Analysis}

The data were analyzed by analysis of variance. The differences between treatments were tested further by Duncan's New Multiple Range Test. Data processing was done by using the SPSS program 17.0 for Windows Evaluation Version (Oramahi, 2008).

\section{RESULTS AND DISCUSSION}

\section{Chemical Composition of Meat Water Content}

The effect of CPO protected by formaldehyde on water content of lamb is presented in Table 1. The results showed that the addition of CPO in the basal diet (R1) caused a decrease in the water content of the meat $(\mathrm{P}<0.05)$ about $1.76 \%$ compared to sheep that were given basal diet (R0). The decrease in water content was much higher $(\mathrm{P}<0.05)$, i.e. $2.83 \%$, in sheep fed $\mathrm{CPO}$ protected with formaldehyde in the basal diet (R2), but it was not significantly different than that of R1. The decrease in water content was 
Table 1. Average of Water, Protein, Fat and Ash Content (\%) on Lamb

\begin{tabular}{lccc}
\hline \multirow{2}{*}{ Chemical Content } & \multicolumn{3}{c}{ Treatments } \\
\cline { 2 - 4 } & R0 & R1 & \multicolumn{1}{c}{ R2 } \\
\hline Water (\%) & $76.78 \pm 1.04^{\mathrm{a}}$ & $75.02 \pm 0.51^{\mathrm{b}}$ & $73.95 \pm 0.73^{\mathrm{b}}$ \\
Protein (\%) & $18.21 \pm 0.29^{\mathrm{b}}$ & $19.03 \pm 0.45^{\mathrm{a}}$ & $19.62 \pm 0.39^{\mathrm{a}}$ \\
Fat (\%) & $3.12 \pm 0.35^{\mathrm{b}}$ & $3.83 \pm 0.48^{\mathrm{ab}}$ & $4.39 \pm 0.46^{\mathrm{a}}$ \\
Ash (\%) & $1.39 \pm 0.39$ & $1.35 \pm 0.35$ & $1.32 \pm 0.22$ \\
\hline
\end{tabular}

$\mathrm{ab}$ : Different superscripts in the same row indicate significant difference $(\mathrm{P}<0.05)$.

due to an increase in fat content that was negatively correlated to the water content. The water content in this study ranged from 73.95 to $76.78 \%$. Water is the largest component of meat, namely $75 \%$ (Lawrie, 2003) with a range of 6080\% (Forrest et al., 1975). Manso et al. (2009) reported that the addition of sunflower oil (SFO) in Merino sheep diet obtained $75.20 \%$ of water content.

\section{Protein Content}

The effect of CPO protected by formaldehyde on protein content in lamb is presented in Table 1. The results showed that the addition of CPO in the basal diet (R1) causes an increase in protein levels $(\mathrm{P}<0.05)$ by $0.82 \%$ compared to sheep that were given basal diet (R0). The increase of protein content was much higher $(\mathrm{P}<0.05)$, i.e. $1.41 \%$, in sheep fed CPO protected by formaldehyde in the basal diet (R2), but it was not significantly different than that of $\mathrm{R} 1$. The increase is due to increase of rumen microbial protein that might accumulate in the meat, it was caused by the availability of $\mathrm{N}$, the source of energy and carbon skeleton as a precursor for the synthesis of microbial protein (Tiven et al., 2011). The increase of this protein content in line with Kitessa et al. (2003) who reported that protected tuna oil (PTO) with formaldehyde can increase the protein content of milk in lactating sheep from $54 \mathrm{~g} / \mathrm{kg}$ to $56 \mathrm{~g} / \mathrm{kg}$.

The protein content in this study ranged from 18.21 to $19.62 \%$. Meat contains protein by $19 \%$ with a range between 16-22\% (Forrest et al., 1975). The results of this study is higher than the research of Manso et al. (2009) which added hydrogenated palm oil (HPO) and sunflower oil (SFO) in Merino sheep diet, obtained the protein content of $17.63 \%$ and $19.27 \%$.

\section{Fat Content}

The effect of CPO protected by formaldehyde on fat content in lamb is presented in Table 1. The results showed that the addition of $\mathrm{CPO}$ in the basal ration (R1) increased the fat content $(\mathrm{P}<0.05)$ by $0.71 \%$ compared to sheep that were given only the basal ration (R0). This increase is due to the extra fat from palm oil in the diet. Increase of fat content was much higher $(\mathrm{P}<0.05)$, i.e. $1.27 \%$, in sheep fed CPO protected with formaldehyde in the basal ration (R2). The increase is due to formaldehyde can protect CPO fat; especially unsaturated fatty acids and reduce microbial degradation in the rumen, so that it can accumulate in the meat. The protection of CPO with formaldehyde can increase unsaturated fatty acids, i.e. oleic, linoleic and linolenic acid $(\mathrm{P}<0.01)$ (Tiven et al, 2011). The increase of fat content is in line with the research of Kitessa et al. (2003) which protected tuna oil (PTO) with formaldehyde, can increase the fat content of milk in lactating sheep from $74 \mathrm{~g} / \mathrm{kg}$ to $77 \mathrm{~g} / \mathrm{kg}$.

Fat content in this study ranged from 3.12 to $4.39 \%$. According to Forrest et al. (1975), meat fat content is about $2.5 \%$ with a range between 1.5 to $13 \%$. The results of this study is higher than the research of Manso et al. (2009) which reported that the addition of hydrogenated palm oil (HPO) and sunflower oil (SFO) in Merino sheep rations, gained fat content of $2.46 \%$ and $3.20 \%$. According to Savell and Cross reported by Soeparno (2005), the fat content of beef accepted by the consumer is about $3-7 \%$. Referring to the statement, the lamb produced in this study might be accepted by consumers, because the fat content is within that range. 


\section{Ash Content}

The effect of CPO protected by formaldehyde on ash content in lamb is presented in Table 1. The results showed that the addition of $\mathrm{CPO}$ in the basal ration (R1) and CPO with formaldehyde in the basal ration (R2) were not significantly affect on ash content of lamb. The average ash content in this study was $1.35 \%$. The ash content is also influenced by the fat content, which is negatively correlated to the ash content. According to Forrest et al. (1975), ash content was influenced by the fat content, the higher the fat content of meat, the lower the ash content. The addition of sunflower oil (SFO) in Merino sheep diet, gained $3.20 \%$ of fat content and $1.64 \%$ of ash content, whereas the diet without the addition of oil (control) gained $2.73 \%$ of fat content and $1.79 \%$ of ash content (Manso et al., 2009). Most of the minerals relatively contained in lean meat because mineral components were primarily associated with water and meat protein (Soeparno, 2005).

\section{Meat Physical Properties Meat pH}

The results showed that the addition of $\mathrm{CPO}$ in the basal diet (R1) and CPO protected with formaldehyde in the basal diet (R2) were not significantly affect on meat $\mathrm{pH}$ (Table 2). The average value of meat $\mathrm{pH}$ was 6.22 , that was higher than the ultimate meat $\mathrm{pH}$, with a range of 5.8 (Soeparno, 2005). The high value of ultimate $\mathrm{pH}$ was due to low muscle glycogen reserves when it was slaughtered so that the accumulation of lactic acid stopped, because muscle glycogen reserves was exhausted before the meat ultimate $\mathrm{pH}$ was reached. Stress before slaughtered, such as: weighing livestock, can reduce muscle glycogen. According to Lawrie (2003), glycogen can reduce because the livestock are tired, hungry or scared before slaughtered. This $\mathrm{pH}$ value is lower than the study of Cooper et al. (2004), which used protected linseed and soya bean (protected linseed and soybean - PLS) with formaldehyde in sheep diet obtained meat $\mathrm{pH}$ value of 6.52 at 45 minutes after slaughtered, whereas after 24 hours the $\mathrm{pH}$ value became 5.68.

\section{Water Holding Capacity (WHC)}

The effect of CPO protected by formaldehyde on lamb WHC is presented in Table 2. The results showed that the addition of $\mathrm{CPO}$ in the basal diet (R1) and CPO protected with formaldehyde in the basal diet (R2) were not significantly affect on meat WHC. The average value of meat WHC was $25.47 \%$. The value of WHC was influenced by the meat $\mathrm{pH}$. Large drop of postmortem $\mathrm{pH}$ will affect on WHC, i.e. the higher of ultimate $\mathrm{pH}$, less of WHC (Lawrie, 2003).

\section{Tenderness}

The effect of CPO protected by formaldehyde on lamb tenderness is presented in Table 2. The results showed that the addition of $\mathrm{CPO}$ in the basal ration (R1) was not significantly affect on the tenderness of lamb compared to those that were given only the basal diet (R0). However, the addition of $\mathrm{CPO}$ protected with formaldehyde in the basal ration (R2) made the lamb become tenderer $(\mathrm{P}<0.01)$ compared to lamb from sheep given only the basal diet (R0) and sheep given the basal diet with the addition of CPO (R1), each at $3.93 \mathrm{~kg} / \mathrm{cm}^{2}$ and $2.69 \mathrm{~kg} / \mathrm{cm}^{2}$. Better meat tenderness in treatment $\mathrm{R} 2$ was affected by the higher of saturated fatty acids content, compared to R1 and R0. Mauger et al. (2003) stated that the high saturated fatty acids caused ruminant fat becomes harder and can lead to cardiovascular disease in consumers.

There are three categories of tenderness on Warner Bratzler shear force tool, namely (1) padded (scale 0-3), (2) quite soft (scale 3-6) and (3) tough (scale 6-11). The value of tenderness in the treatment of R0 $\left(7.78 \mathrm{~kg} / \mathrm{cm}^{2}\right)$ and R1 $(6.54$ $\mathrm{kg} / \mathrm{cm}^{2}$ ) were categorized tough, while the R2 treatment $\left(3.85 \mathrm{~kg} / \mathrm{cm}^{2}\right)$ was categorized quite soft. Gilbert et al. (2003) that protected lipids with casein and formaldehyde, found the beef tenderness score about $3.39 \mathrm{~kg} / \mathrm{cm}^{2}$.

\section{Cooking Loss}

The effect of CPO protected by formaldehyde on lamb cooking loss can be seen in Table 2. The addition of CPO in the basal diet (R1) was not significantly affect on meat cooking loss, compared to meat from sheep given only the basal diet (R0). The addition of CPO protected with formaldehyde (R2) in the diet made cooking loss that was lower $(\mathrm{P}<0.01)$ than lamb from sheep given only the basal diet (R0) and lam from sheep given the basal diet with the addition of CPO (R1), each at by $7.63 \%$ and $7.98 \%$. The low meat cooking loss on R2 treatment was influenced by the higher fat content of meat compared to R0 and R1 (Table 2). According to Forrest et al. (1975), that the cooking loss was influenced by the fat content in meat and fat translocation. 
Table 2. The Average of $\mathrm{pH}, \mathrm{WHC}(\%)$, Tenderness $\left(\mathrm{kg} / \mathrm{cm}^{2}\right)$ and Cooking Loss (\%) on Lamb

\begin{tabular}{lccc}
\hline \multirow{2}{*}{ Meat Physical Properties } & \multicolumn{3}{c}{ Treatments } \\
\cline { 2 - 4 } & R0 & R1 & R2 \\
\hline pH & $6.17 \pm 0.11$ & $6.25 \pm 0.15$ & $6.24 \pm 0.15$ \\
WHC (\%) & $24.61 \pm 1.33$ & $25.74 \pm 1.78$ & $26.06 \pm 1.49$ \\
Tenderness $\left(\mathrm{kg} / \mathrm{cm}^{2}\right)$ & $7.78 \pm 0.52^{\mathrm{a}}$ & $6.54 \pm 1.27^{\mathrm{a}}$ & $3.85 \pm 0.40^{\mathrm{b}}$ \\
Cooking Loss $(\%)$ & $44.70 \pm 1.18^{\mathrm{a}}$ & $45.05 \pm 1.30^{\mathrm{a}}$ & $37.07 \pm 1.35^{\mathrm{b}}$ \\
\hline
\end{tabular}

Different superscripts in the same row indicate highly significant difference $(\mathrm{P}<0.01)$

During cooking, the fat will melt and distributed in the meat so the meat that has marbling will have smaller cooking losses. According to Soeparno (2005), the equitable distribution of fat throughout the meat can act as a barrier liquid to escape during cooking. Generally, cooking loss varies with the range of $15-40 \%$ (Soeparno, 2005). The meat with low cooking loss relatively has a better quality than the meat with high cooking loss, because of little nutrients loss during cooking.

\section{CONCLUSION}

The CPO protected by formaldehyde in the diet can increase meat protein and fat content, and produce tenderer lamb with lower cooking loss.

\section{ACKNOWLEDGMENT}

The authors would like to thank PT. Indofood, Tbk, for the financial support through the Indofood Riset Nugraha Program (IRN) 2011.

\section{REFERENCES}

AOAC. 2005. Official Methods of Analysis. $11^{\text {th }}$ Ed. Association of Official Analytical Chemists. Washington, DC.

Bauman, D. E., J. W. Perfield, M. J. de Veth and A. L. Lock. 2003. New perspectives on lipid digestion and metabolism in ruminants. Proc. Cornell Nutr. Conf. Feed Manuf., Syracuse, NY. Cornell Univ., Ithaca, NY. P. 175-189

Cooper, S. L., L. A. Sinclair, R. G. Wilkinson, K. G. Hallett, M. Enser and J. D. Wood. 2004. Manipulation of the $n-3$ polyunsaturated acid content of muscle and adipose tissue in lambs. J. Anim. Sci. 82:1461-1470

de Veth, M. J., S. K. Gulati, N. D. Luchini and D. E. Bauman. 2005. Comparison of calcium salts and formaldehyde-protected conjugated linoleic acid in inducing milk fat depression. J. Dairy Sci. 88:1685-1693

Forrest, J. C., E. D. Aberle, H. B. Hedrick, M. D. Judge and R. A. Merkel. 1975. Principles of Meat Science. W. H. Freeman and Co., San Francisco.

Gilbert, C. D., D. K. Lunt, R. K. Miller and S. B. Smith. 2003. Carcass, sensory, and adipose tissue traits of Brangus steers fed caseinformaldehyde-protected starch and/or canola lipid. J. Anim. Sci. 81:2457-2468

Hristov, A. N., P. M. Vander, M. Agle, S. Zaman and C. Schneider. 2009. Effect of lauric acid and coconut oil on ruminal fermentation, digestion, ammonia losses from manure, and milk fatty acid composition in lactating cows. J. Dairy Sci. 92: 5561-5582.

Jenkins, T. C., R. J. Wallace, P. J. Moate and E. E. Mosley. 2008. Board-Invited Review: Recent advances in biohydrogenation of unsaturated fatty acids within the rumen microbial ecosystem. J. Anim. Sci. 86:397412.

Kitessa, S. M., S. K. Gulati, J. R. Ashes, E. Fleck, T. W. Scott, and P. D. Nichols. 2001. Utilisation of fish oil in ruminants. I. Fish oil metabolism in sheep. J. Anim. Feed Sci. Technol. 89:189-199.

Kitessa, S. M., D. Peake, R. Bencini and A. J. Williams. 2003. Fish oil metabolism in ruminants. III. Transfer of $n-3$ polyunsaturated fatty acids (PUFA) from tuna oil into sheep's milk. J. Anim. Feed 
Sci. Technol. 108:1-14.

Lawrie, R. A., 2003. Ilmu Daging. $5^{\text {th }}$ Ed. Translated by A.Parakkasi and Y.Amwila. Penerbit Universitas Indonesia (UI-Press), Jakarta.

Mauger, J. F., A. H. Lichtenstein, L. M. Ausman, S. M. Jalbert, M. Jauhiainen, C. Ehnholm, and B. Lamarche. 2003. Effect of different forms of dietary hydrogenated fats on LDL particle size. Am. J. Clin. Nutr. 78: 370-375.

Manso, T., R. Bodas, T. Castro, V. Jimeno and A. R. Mantecon. 2009. Animal performance and fatty acid composition of lambs fed with different vegetable oils. Meat Sci. 83:511-516.

Oramahi, H. A. 2008. Analisis Data dengan SPSS \& SAS. Studi Kasus Bidang Pertanian, Kehutanan dan Peternakan, Ardana Media, Yogyakarta.

Soeparno. 2005. Ilmu dan Teknologi Daging. $4^{\text {th }}$ Ed. Gadjah Mada University Press, Yogyakarta.

Suryati, T., I. I. Arif and B. N. Polii. 2008. Korelasi dan kategori keempukan daging berdasarkan hasil pengujian menggunakan alat dan panelis. Animal Production. 3(10):188-193.

Tiven, N. C., L. M. Yusiati., Rusman and U. Santoso. 2011. Ketahanan asam lemak tidak jenuh dalam crude palm oil terproteksi terhadap aktivitas mikrob rumen domba in vitro. Media Peternakan. 34(1):42-49.

Vafa, T. S., A. A. Naserian and A. R. H. Moussavi. 2009. Effect of different levels of fish oil and canola oil on in vitro and in vivo nutrient digestibility. Res. Biol. Sci. 4:12211226

Wang, Y. M., J. H. Wang., C. Wang., B. Chen., J. X. Liu., H. Cao., F. C. Guo and M. Vázquez-Anón. 2010. Effect of different rumen-inert fatty acids supplemented with a dietary antioxidant on performance and antioxidative status of early-lactation cows. J. Dairy Sci. 93:3738-3745

Wood, J. D., M. Enser, A. V. Fisher, G. R. Nute, P. R. Sheard, R. I. Richardson, S. I. Hughes, and F. M. Whittington. 2008. Fat deposition, fatty acid composition and meat quality. Review. Meat Sci. 78:343-358 